\title{
Gambaran Pengetahuan dan Sikap Ibu Nifas Tentang Bounding Attachment di Ruangan Seruni Rumah Sakit PMI Kota Bogor
}

\author{
Faizahannisa Ana ${ }^{1)}$, Surtiati Eti ${ }^{1}$ \\ ${ }^{1}$ Prodi Keperawatan Bogor Poltekkes Bandung \\ Email: ana.faizahannisa@gmail.com
}

\begin{abstract}
ABSTRAK : Bounding Attachment adalah interaksi fisik dan emosional orangtua dan bayi yang dapat memberikan ikatan batin kepada bayi sehingga bayi merasa dicintai dan dimiliki. Dasar terbentuknya hubungan yang sehat bagi bayi dalam kehidupan selanjutnya merupakan kesuksesan Bounding Attachment antara ibu dan bayi. Tujuan Penelitian ini adalah untuk mengetahui gambaran pengetahuan dan sikap ibu nifas tentang Bounding Attachment. Desain penelitian ini adalah deskriptif. Cara pengambilan sampel yang digunakan adalah Purposive Sampling dengan responden sebanyak 42 orang. Hasil penelitian ini menunjukan pengetahuan baik sebanyak 22 orang (53\%), pengetahuan cukup sebanyak 14 orang (33\%) dan pengetahuan kurang sebanyak 6 orang (14\%). Sedangkan untuk sikap yang memiliki sikap positif yaitu sebanyak 23 orang (55\%) dan sikap negatif yaitu sebanyak 19 orang (45\%). Kesimpulan hasil peneltian ini menunjukan bahwa responden paling banyak memiliki pengetahuan baik dan sikap positif tentang Bounding Attachment. Rekomendasi bagi pelayanan kesehatan khususnya perawat maternitas untuk lebih ditingkatkan dalam memberikan penyuluhan kesehatan pada ibu nifas dengan primipara tentang Bounding Attachment selama dirumah sakit.

Kata Kunci : Bounding Attachment, Ibu Nifas, Pengetahuan Tentang Bounding Attachment, Sikap tentang Bounding Attachment

\section{Describtion of Knowlage and Attitude of Postpartum Mother about Bounding Attachment at Room Seruni in PMI hospital Bogor}

\begin{abstract}
Bounding Attachment is pysical and emotional interaction of parent that can give an inner bond to the baby so the baby feels loved and owned. The foundation of healthy relationships for the baby in the next life is a success of Bounding Attachment between mother and baby. The research aimed to know description of knowledge and attitude of postpartum mother about Bounding Attachment. The design of this research was descriptive. Sampling method used purposive sampling with 42 respondents. The result showed good knowledge as much as 22 people (53\%), enough knowledge as much as 14 people (13\%), and less knowledge as much as 6 people (14\%). While, people who had a positive attitude as much as 23 people $(55 \%)$, and the negative attitude as much as 19 people (45\%). The conclusion of this research shows that most respondents had good knowledge and positive attitude about Bounding Attachment. The recommendations for health services especially for maternity nurses should be increased in term providing health education towards postpartum mother with primipara about Bounding Attachment during the hospital.

Keywords : Bounding Attachment, Postpartum Mother, Knowlage about Bounding Attachment, Attitude about Bounding Attachment
\end{abstract}




\section{PENDAHULUAN}

Program kesehatan yang Program kesehatan yang tercantum dalam Renstra Kementerian Kesehatan RI tahun 2015-2019 difokuskan pada empat program prioritas, salah satu program yang diprioritaskan secara garis besar yaitu program penurunan Angka Kematian Ibu dan Bayi. Angka Kematian Bayi (AKB) adalah banyaknya kematian bayi usia di bawah satu tahun, per 1000 kelahiran hidup pada satu tahun tertentu digunakan untuk mencerminkan keadaan derajat kesehatan di suatu masyarakat. ${ }^{1}$ Pada tahun 2013 AKB di dunia adalah 34 per 1000 kelahiran hidup dan Asia Tenggara adalah 24 per 1000 kelahiran hidup. ${ }^{2}$ sedangkan AKB di Indonesia adalah 32 per 1000 kelahiran hidup, ${ }^{3}$ tahun 2013 AKB mencapai 26,6 per 1000 kelahiran hidup dan tahun 2014 mengalami penurunan menjadi 26 per 1000 kelahiran hidup serta tahun 2015 menjadi 25,5 per 1000 kelahiran hidup akan tetapi untuk target Renstra yang ingin dicapai adalah 24 per 1000 kelahiran hidup di tahun 2015 . $^{4}$

Pada tahun 2012 di Jawa Barat, AKB adalah 30 per 1000 kelahiran hidup. $^{5}$ Data kematian BBL di Kota Bogor (0-28 hari) tahun 2012 adalah 18 kasus dan kematian bayi (1-11 bulan) 6 kasus. Sementara di tahun 2015, angka kematian ini kembali mengalami kenaikan untuk kematian BBL (0-28 hari) 51 kasus dan kematian bayi (1-11 bulan) 14 kasus. $^{6}$

Penyebab AKB meningkat dikarenakan kondisi bayi dengan lahir premature, berat badan lahir rendah, asfiksia, tetanus, infeksi, pengetahuan ibu dan masyarakat yang kurang, akses pelayanan kesehatan yang jauh dan faktor sosial-ekonomi yang rendah. $^{7}$ Salah satu upaya untuk mencegah kenaikan AKB adalah dengan Rawat Gabung atau Rooming In. Model Rawat Gabung ini dapat memberikan kesempatan pada ibu dan bayi untuk meningkatkan hubungan batin sejak lahir serta ikatan kasih sayang antara ibu dan bayi atau Bounding Attachment karena disini ibu bisa setiap saat bersama dengan bayinya. ${ }^{8}$

Bounding Attachment adalah sebuah peningkatan hubungan kasih sayang dengan keterkaitan batin antara orang tua dan bayi. Hal ini merupakan proses interaksi yang dilakukan terus-menerus antara bayi dan orang tua yang bersifat saling mencintai. ${ }^{9}$ Sedangkan yang dimaksud dengan kesuksesan Bounding Attachment antara ibu dan anak sampai usia 0-3 tahun karena pada usia 0-3 tahun itu merupakan dasar terbentuknya hubungan yang sehat bagi anak dalam kehidupan selanjutnya. ${ }^{10}$ Untuk perkembangan psikososial bayi 0-1 tahun,berada pada perkembangan psikososial rasa kepercayaan dasar vs ketidakpercayaan. Ketika bayi menyadari ibu akan memberi makan/minum secara teratur, ibu dan bayi belajar dan memperoleh kualitas ego atau identitas ego yang pertama, perasaan kepercayaan dasar (basic trust). ${ }^{11}$ Salah satu kasih sayang seorang ibu dan bayi dapat dilakukan dengan cara pemberian ASI Ekslusif, rawat gabung, kontak mata, suara, aroma, entraiment, boritme dan inisiasi dini. Cara-cara tersebut dapat dilakukan setelah pasca persalinan atau masa nifas. ${ }^{12}$

Postpartum atau masa nifas merupakan periode yang sangat penting untuk diketahui. Nifas adalah periode mulai dari enam jam sampai dengan 42 hari pasca persalinan. Pada masa nifas, ibu akan mendapatkan pengalaman dalam merawat bayinya dan memberikan stimulasi mental dini tumbuh kembang pada bayi. Pada fase inilah terjadi perubahan pada ibu baik fisiologis maupun psikologis. ${ }^{13}$ Salah satu adaptasi psikososial pada ibu nifas adalah dependent phase 1-2 hari, dimana pada fase ini ibu sangat tergantung dalam segala hal termasuk kebutuhan dasarnya disini ibu fokus pada diri sendiri dan ibu tidak berinisiatif untuk bertemu dengan bayinya. Jadi, Bounding Attachment 
harus segera dilakukan saat bayi baru lahir. Banyak hal yang terjadi saat seorang ibu berada pada situasi terpisah dengan bayi yaitu peristiwa perubahan psikis (mental) ibu terhadap bayinya sehingga diperlukan pengetahuan ibu nifas tentang ikatan kasih sayang yang dibentuk secara bertahap antara ibu dan bayi. ${ }^{14}$

Pengetahuan adalah segala informasi atau maklumat yang diketahui atau disadari oleh seseorang. Faktorfaktor yang mempengaruhi pengetahuan diantaranya informasi/media massa, sosial, budaya dan ekonomi, pengalaman, lingkungan, usia. ${ }^{15}$ lbu nifas yang memiliki pengetahuan baik dan pendidikan tinggi mau melakukan Bounding Attachment karena telah mendapatkan informasi dari berbagai media seperti media elektronik dan media cetak. Bila seorang ibu yang sudah mendapatkan informasi tentang Bounding Attachment akan lebih cepat merespon baik tentang informasi tersebut sehingga respon ini merupakan suatu sikap yang bisa positif atau negatif. ${ }^{16}$

Sikap merupakan konsep paling penting dalam psikologi sosial yang membahas unsur sikap baik sebagai individu maupun kelompok. Faktorfaktor yang mempengaruhi sikap diantaranya pengalaman pribadi, pengaruh orang lain yang dianggap penting, pengaruh budaya, media massa, lembaga pendidikan, lembaga agama dan faktor emosional. ${ }^{17}$ Meningkatnya pengetahuan dan METODE

Desain penelitian yang digunakan oleh peneliti adalah deskriptif. Populasi dalam penelitian ini adalah seluruh ibu nifas yang dirawat di Ruangan Seruni Rumah Sakit Palang Merah Indonsia Kota Bogor. Sampel yang digunakan adalah sebagian ibu nifas di Ruangan Seruni Rumah Sakit Palang Merah Indonesia Kota Bogor. Pengumpulan sampel menggunakan metode (Nonprobability Samples) dengan menggunakan teknik purposive perubahan sikap ibu nifas tentang Bounding Attachment maka perubahan fisiologis dan perkembangan psikologis akan sesuai dengan pertumbuhan dan perkembangan bayi normal akan tetapi pada bayi yang kurang mendapatkan interaksi dengan ibu dalam pembentukan ikatan batin akan menimbulkan penyimpangan pola perilaku pada tahap perkembangan berikutnya. ${ }^{16}$

Hasil penelitian yang dilakukan Mahardika Cahyaningrum Tahun 2013 dengan judul Tingkat Pengetahuan lbu Nifas Tentang Bounding Attachment di Rumah Sakit Umum Daerah Kota Surakarta dalam katagori cukup. Ini dikarenakan kurang memanfaatkan media baik media elektornik maupun media cetak khususnya tentang Bounding Attachment. ${ }^{18}$

Hasil studi pendahuluan yang dilakukan peneliti pada tanggal 1 April 2017 di Ruangan Seruni Rumah Sakit Palang Merah Indonesia Kota Bogor melalui teknik wawancara tentang Bounding Attachment yang terdiri dari 5 ibu nifas terdapat 2 ibu nifas yang mengetahui tentang Bounding Attachment dan 3 ibu nifas yang belum mengetahui tentang Bounding Attachment. Berdasarkan gambaran diatas peneliti tertarik untuk melakukan penelitian yang berjudul Gambaran Pengetahuan dan Sikap Ibu Nifas Tentang Bounding Attachment di Ruangan Seruni Rumah Sakit Palang Merah Indonesia Kota Bogor.

sampling yaitu pengambilan sampel didasarkan pada suatu pertimbangan tertentu yang dibuat oleh peneliti sendiri, berdasarkan ciri atau sifat-sifat populasi yang sudah diketahui sebelumnya. ${ }^{19}$ Sehingga didapatkan jumlah sampel sebanyak 42 ibu nifas dengan kriteria inkulsi adalah lbu nifas primigravida, multigravida dan grandegravida yang telah melahirkan secara normal maupun post SC, Ibu nifas yang rawat bersama dengan bayi (Rooming In), Ibu nifas yang melakukan IMD setelah melahirkan dan lbu nifas 
yang memiliki kesadaran penuh, lbu nifas yang mampu membaca di Ruangan Seruni Rumah Sakit Palang Merah Indonesia Kota Bogor dan ibu nifas yang bersedia dijadikan responden. Adapun Kriteria Eklusi dalam penelitian ini subjek yang dikeluarkan atau tidak diambil adalah lbu nifas dengan komplikasi yang berat, lbu nifas yang mengalami penurunan kesadaran, Ibu nifas yang terpasang alat bantu medis seperti oksigenasi, NGT (Nasogastric Tube), transfusi darah dan lain-lain serta Ibu nifas yang mengalami kesakitan atau nyeri yang berat.

Instrumen dalam penelitian ini terdiri dari kuesioner A berisikan data tentang demografi yaitu usia, pendidikan, pekerjaan dan paritas. Pengisian dilakukan dengan cara mengisi data pada tempat yang telah disediakan. Kuesioner B berisikan tentang 10 pertanyaan tentang Bounding Attachment. Pada kuesioner $B$ jika jawaban Benar diberi skor 1 dan

\section{HASIL}

Tabel 1. Proporsi Responden Berdasarkan Usia Di Ruangan Seruni Rumah Sakit Palang Merah Indonesia Kota Bogor, Juni 2017 $(n=42)$

\begin{tabular}{cccc}
\hline No & Usia & $\mathrm{n}$ & $\%$ \\
\hline 1 & $<20$ Tahun & 1 & $2 \%$ \\
2 & $20-35$ Tahun & 34 & $81 \%$ \\
3 & $>35$ Tahun & 7 & $17 \%$ \\
& Jumlah & 42 & $100 \%$ \\
\hline
\end{tabular}

Berdasarkan Tabel 1 didapatkan data bahwa sebagian besar responden berusia 20-35 Tahun sebanyak 34 orang $(81 \%)$ dan sebagian kecil responden berusia $<20$ Tahun sebanyak 1 orang (2\%). jawaban salah diberi skor 0 . Hasil ukur pengetahuan adalah baik jika $76-100 \%$, pengetahuan cukup 56-75\%, dan pengetahuan kurang $<56 \%$. Kuesioner $\mathrm{C}$ berisi dengan 10 pernyataan tentang sikap yang terdiri dari 5 pernyataan positif dan 5 pernyataan negatif. Pengisian dilakukan dengan cara memberikan tanda checklist $(\sqrt{ })$ pada kolom yang tersedia dengan pilihan Sangat Setuju (SS), Setuju (S), Tidak Setuju (TS) dan Sangat Tidak Setuju (STS). Positif jika hasil skor $\geq 34$, negatif jika hasil skor $<34$. Peneliti menggunakan alat ukur pengukuran data berupa kuesioner. Pengolahan data terdiri dari Editing, Coding, Data Entry, Pembersihan Data (Cleaning) dan Data File.

Analisa data dengan menggunakan analisa univariat yaitu analisis yang dilakukan terhadap tiap variabel dari hasil penelitian dalam analisis ini hanya menghasilkan distribusi dari presentasi tiap variabel. ${ }^{20}$

Tabel 2. Proporsi Responden Berdasarkan Pendidikan Di Ruangan Seruni Rumah Sakit Palang Merah Indonesia Kota Bogor, Juni $2017(n=42)$

\begin{tabular}{cccc}
\hline No & Pendidikan & $\mathrm{n}$ & $\%$ \\
\hline 1 & SD & 5 & $12 \%$ \\
2 & SMP & 3 & $7 \%$ \\
3 & SMA & 19 & $45 \%$ \\
4 & PT & 15 & $36 \%$ \\
& Jumlah & 42 & $100 \%$ \\
\hline
\end{tabular}

Berdasarkan Tabel 2. didapatkan data bahwa kurang dari setengah responden memiliki pendidikan SMA sebanyak 19 orang $(45 \%)$ dan sebagian kecil responden memiliki pendidikan SMP sebanyak 3 orang (7\%). 
Tabel 3. Proporsi responden berdasarkan paritas di Ruangan Seruni Rumah Sakit Palang Merah Indonesia Kota Bogor, Juni $2017(n=42)$

\begin{tabular}{cccc}
\hline No & Paritas & $\mathrm{n}$ & $\%$ \\
\hline 1 & Primipara & 19 & $45 \%$ \\
2 & Multipara & 22 & $52 \%$ \\
3 & Grandemultipara & 1 & $3 \%$ \\
& Jumlah & 42 & $100 \%$ \\
\hline
\end{tabular}

Berdasarkan Tabel 3. didapatkan data bahwa lebih dari setengahnya responden Multipara sebanyak 22 orang $(52 \%)$ dan sebagian kecil grandepara sebanyak 1 orang (3\%).

Tabel 4. Proporsi Responden Berdasarkan Pekerjaan Di Ruangan Seruni Rumah Sakit Palang Merah Indonesia Kota Bogor, Juni $2017(n=42)$

\begin{tabular}{clcc}
\hline No & Pekerjaan & $\mathrm{n}$ & $\%$ \\
\hline 1 & Bekerja & 14 & $33 \%$ \\
2 & Tidak Bekerja & 28 & $67 \%$ \\
& Jumlah & 42 & $100 \%$ \\
\hline
\end{tabular}

Berdasarkan Tabel 5.4 didapatkan data bahwa lebih dari setengahnya responden sebanyak 28 orang (64\%) tidak bekerja dan kurang dari setengah responden sebanyak 14 orang (33\%) bekerja.

Tabel 5. Proporsi Responden Pengetahuan Ibu Nifas Tentang Bounding Attachemnt Di Ruangan Seruni Rumah Sakit Palang Merah Indonesia Kota Bogor, Juni 2017 ( $n=42)$

\begin{tabular}{cccc}
\hline No & Pengetahuan & N & $\%$ \\
\hline 1 & Baik & 22 & $53 \%$ \\
\hline 2 & Cukup & 14 & $33 \%$ \\
\hline 3 & Kurang & 6 & $14 \%$ \\
\hline & Jumlah & 42 & $100 \%$ \\
\hline
\end{tabular}

Berdasarkan Tabel 5. didapatkan data bahwa lebih dari setengah responden sebanyak 22 orang (52\%) memiliki pengetahuan baik dan sebagian kecil responden sebanyak 6 orang (14\%) memiliki pengetahuan kurang.

Tabel 6. Nilai Mean, Median, Modus, Tertinggi dan terendah Sikap Responden Tentang Bounding Attachment

\begin{tabular}{cc}
\hline Mean & 34,65 \\
Median & 34 \\
Modus & 39 \\
Nilai Tertinggi & 40 \\
Nilai Terendah & 16 \\
\hline
\end{tabular}

Berdasarkan Tabel 6. memaparkan bahwa dari sikap ibu nifas tentang Bounding Attachement menunjukan nilai mean 34,65 , nilai median 34 , modus 39 , nilai tertinggi 40 dan nilai terendah 18.

Tabel 7. Proporsi Responden Sikap Ibu Nifas Tentang Bounding Attachemnt Di Ruangan Seruni Rumah Sakit Palang Merah Indonesia Kota Bogor, Juni 2017 ( $n=42)$

\begin{tabular}{cccc}
\hline No & Sikap & N & $\%$ \\
\hline 1 & Positif & 23 & $55 \%$ \\
2 & Negatif & 19 & $45 \%$ \\
& Jumlah & 42 & $100 \%$ \\
\hline
\end{tabular}

Berdasarkan Tabel 7. didapatkan data bahwa lebih dari setengah responden sebanyak 23 orang (55\%) memiliki sikap Positif dan kurang dari setengah responden sebanyak 19 orang (45\%) memiliki sikap negatif.

\section{PEMBAHASAN}

1. Karakteristik Responden

a. Usia

Hasil penelitian yang dilakukan oleh penelti menunjukan bahwa dari 42 orang terdapat sebagian besar ibu dengan usia 20-35 
tahun sebanyak 34 orang. Hasil penelitian ini sesuai dengan teori Arini H (2012), menjelaskan bahwa ibu dengan usia 20-35 tahun sebagai masa dewasa atau masa reproduksi, dimana pada masa ini ibu telah mampu memecahkan masalahmasalah yang dihadapi dengan tenang secara emosional, terutama dalam menghadapi kehamilan, persalinan, nifas dan merawat bayinya. ${ }^{20}$

b. Pendidikan

Hasil penelitian yang diakukan peneliti menunjukan bahwa dari 42 orang terdapat kurang dari setengah ibu nifas berpendidikan SMA sebanyak 19 orang. Hasil penelitian ini sesuai dengan teori Arini $\mathrm{H}$ (2012), mengatakan bahwa ibu yang memiliki pendidikan tinggi umumnya akan menerima perubahan dalam hal pemeliharaan kesehatan. ${ }^{19}$ Hasil penelitian ini juga sejalan dengan penelitian Abubakar dan Mutiara (2013), mengatakan bahwa ibu nifas yang memiliki pendidikan tinggi akan memperkaya dirinya dengan ilmu-ilmu yang berguna dalam perawatan bayi baru lahir. ${ }^{16}$

c. Paritas

Hasil penelitian menunjukan bahwa dari 42 orang terdapat lebih dari setengah ibu dengan multipara sebanyak 22 orang dimana ibu dengan multipara memiliki pengalaman dalam melahirkan bayi hidup lebih dari 2 kali. Hasil penelitian ini sejalan dengan teori Notoatmojo (2012), pengalaman adalah suatu cara untuk memperoleh kebenaran pengetahuan dengan mengulang kembali pengetahuan yang diperoleh dalam memecahkan masalah yang dihadapi masalalu. ${ }^{19}$

d. Pekerjaan
Hasil penelitian menunjukan bahwa dari 42 orang didapatkan lebih dari setengah ibu nifas yang tidak bekerja sebanyak 28 orang, ibu lebih memilih untuk mengurus rumah tangga dan merawat anaknya. Peneliti berpendapat bahwa ibu nifas yang tidak bekerja dapat mempengaruhi pengetahuan tentang Bounding Attachment karena ibu nifas lebih memiliki banyak waktu dalam mencari informasi tentang Bounding Attachment.

\section{Pengetahuan Responden Tentang} Bounding Attachment

Hasil penelitian yang dilakukan oleh peneliti menunjukan bahwa dari 42 orang terdapat ibu nifas yang memiliki pengetahuan baik sebanyak 22 orang, pengetahuan cukup sebanyak 14 orang dan pengetahuan kurang sebanyak 6 orang tentang Bounding Attachment. Data ini menunjukan lebih dari setengah ibu nifas memiliki pengetahuan baik. Hasil penelitian ini tidak sejalan dengan penelitian yang dilakukan oleh peneliti Mahardika Cahyaningrum dengan judul penelitian Tingkat Pengetahuan lbu Nifas Tentang Bounding Attachment di Rumah Sakit Umum Daerah Kota Surakarta, berdasarkan analisa dan data yang didapatkan bahwa dari 47 orang dengan pengetahuan baik sebanyak 4 orang, pengetahuan cukup sebanyak 29 orang dan pengetahuan kurang sebanyak 14 orang. ${ }^{19}$ Hasil penelitian ini terjadi karena tempat penelitian yang dilakukan oleh peneliti merupakan rumah sakit swasta tipe $B$ yang telah menerapkan metode rawat gabung/ Rooming In antara ibu dan bayi di Ruangan Seruni Rumah Sakit Palang Merah Indonesia Kota Bogor sehingga perawat selalu memberikan edukasi kepada ibu nifas berupa penyuluhan kesehatan 
tentang Bounding Attachment dan memberikan intervensi tentang Bounding Attachment. Hasil penelitian ini sejalan dengan penelitian Abubakar dan Mutiara (2013), mengatakan bahwa ibu nifas yang memiliki pengetahuan baik akan melakukan Bounding Attachment. ${ }^{16}$

\section{Sikap responden tentang Bounding} Attachement

Hasil penelitian menunjukan bahwa sikap ibu nifas Tentang Bounding Attachment di Ruangan Seruni Rumah Sakit Palang Merah Indonesia Kota Bogor dari 42 orang, lebih dari setengah ibu nifas memiliki sikap positif sebanyak 23 orang dan kurang dari setengah responden sikap negatif sebanyak 19 orang. Data ini menunjukan bahwa lebih dari setengah memiliki sikap positif dengan hasil median $\geq 34$. Peneliti berpendapat bahwa sikap positif tersebut didapatkan karena ibu nifas yang mengharapkan kehadiran bayi akan memberikan respon fisik maupun emosional seperti menyentuh dan memberikan senyuman kepada bayi dan cenderung mendekati serta merasa senang dengan kehadiran bayinya. Selain itu, untuk meningkatkan sikap positif pada ibu nifas dengan memberikan stimulus kepada ibu untuk memberikan kesempatan berdua dengan bayinya dan sikap tersebut dipengaruhi oleh berbagai faktor-faktor yang mempengaruhi sikap. Hasil penelitian ini sejalan dengan teori Notoatmojo (2012), Sikap merupakan respon tertutup seseorang terhadap stimulus atau objek tertentu, yang sudah melibatkan faktor pendapat dan emosi yang bersangkutan (senang tidak senang, setuju-tidak setuju, baik- tidak baik, dan sebagainya). ${ }^{19}$ Adapun faktor yang mempengaruhi sikap yaitu pengalaman pribadi, pengaruh orang lain yang dianggap penting, pengaruh budaya, media massa, lembaga pendidikan dan lembaga agama dan faktor eksternal seperti pernyataan yang disadari dari emosional. ${ }^{17}$

\section{KESIMPULAN}

1. Karakteristik responden sebagian besar berusia antara 20-35 tahun, kurang dari setengah berpendidikan SMA dan lebih dari setengah ibu nifas dengan multipara serta lebih dari setengahnya ibu nifas tidak bekerja.

2. Dalam penelitian ini didapatkan lebih dari setengahnya memiliki pengetahuan baik tentang Bounding Attachment.

3. Dalam penelitian ini didapatkan lebih dari setengahnya memiliki sikap positif tentang Bounding Attachement.

\section{DAFTAR PUSTAKA}

1. Kemenkes, RI .2015. Pendoman Umum Program Indonesia Sehat dengan Pendekatan Keluarga. Kemenkes RI.

2. BPS .2016. Meski Angka Kematian Bayi di Indonesia MasihTinggi.http://databoks.k atadata.co.id/datapublish/201 6/11/25/25/meskiangkakemat ian-bayi-diindonesia-masih tinggi diakses pada tanggal 20 Maret, 2017.

3. SDKI.2012.Survei Demografi dan Kesehatan Indonesia. http://microdata.bps.go.id/mik rodata/index.php/catalog/sdki diakses pada tanggal 20 Februari 2017.

4. Kemenkes RI. 2013. Pusat Data dan Informasi Profil Kesehatan Indonesia Tahun 2012. Jakarta: Kemenkes RI.

5. Dinkes. 2012. Profil Kesehatan Provinsi Jawa 
Barat Tahun 2012. Bandung: Dinas Kesehatan.

6. Donni, 2016. Kurangi Angka Kematian lbu dan Bayi Baru Lahir di Kota Bogor. http://kotabogor.go.id/index.p hp/show_post/detail/3191/kur angi-angka-kematian-ibudan-bayi-baru-lahir-dinkeskota-bogor diakses pada tanggal 21 Februari 2017.

7. Badan penelitian dan pengembangankesehatan.20 17. riset kesehatan dasar (Riskesdas,2007).Kementeri an kesehatan RI.

8. Maryati, Dwi, Sujianti dan Budiarti, Tri. 2011. Buku Ajar Neonates, Bayi dan Balita. Jakarta: Trans Info Media.

9. Handayani, Esti dan Pujiastuti, Wahyu. 2016. Asuhan Holistik Masa Nifas dan Menyusui. Yogyakarta: Trans Medika.

10. Syarifudin, Karningsih Dan Dairi, M. 2011. Untaian Materi Penyuluhan KIA (Kesehatan Ibu Dan Anak). Jakarta: Trans Info Media.

11. Kyle, Terri.2015. Buku Ajar Keperawatan Pediatric Ed2, Vol 1. Jakarta : EGC.

12. Maryati, Dwi, Sujianti dan Budiarti, Tri. 2011. Buku Ajar Neonates, Bayi dan Balita. Jakarta: Trans Info Media.

13. Indriyani, Diyan. 2016. Edukasi Postnatal dengan Pendekatan Family Centered Maternity Care (FCMC).Yogyakarta: Trans Medika.

14. Novita, Regina. 2011. Keperawatan Maternitas. Bogor: Ghalia Indonesia.

15. Hasmi. 2016. Metode Penelitian Epidemiologi-Edisi Revisi. Jakarta: Trans Info Media.

16. Mutiara, Kurnia dan Abu bakar. 2013. Hubungan Paritas, Pengetahuan dan
Pendidikan dengan Bounding Attachment pada Ibu Nifas di Rumah Sakit Ibu dan Anak Bereuneun Kabupaten Pidie Tahun2013.http://journal.stik eseub.ac.id/index.php/jkeb/ar ticle/view/197 diakses pada tanggal 27 Februari 2017.

17. Wawan, A dan Dewi M. 2011.Teori Pengukuran Pengetahuan Sikap dan Perilaku Manusia, Cetakan Ke-dua. Yogyakarta: Nuha Media.

18. Cahyaningrum, Mahardika. 2013. Tingkat Pengetahuan Ibu Nifas Tentang Bounding Attachment di Rumah Sakit Umum Daerah Kota Surakarta.http://digilib.stikesk usumahusada.ac.id/files/disk 1/7/01-gdl-mahardikac-3331-ktimaha-1.pdf diakses pada tanggal 27 Februari 2017.

19. Notoatmojo. 2012. Metodologi Penelitian Kesehatan. Jakarta: Rineka Cipta.

20. Arini, H. 2012. Mengapa Seorang lbu Harus Menyusui?. Yogyakarta: Flash Book. 